\title{
The Importance of Community Understanding of Political Ethics and Culture in Developing A Democratic Political Culture in Indonesian Regions
}

\author{
Suko Wiyono ${ }^{1}$ (D), Wahyu Hindiawati ${ }^{2}$ (D), Dhian Kartikasari ${ }^{3} 8(D)$, and Zulfikar Ramadhan 48 (D) \\ ${ }^{1}$ Professor, Faculty of Social Science, Universitas Negeri Malang, Indonesia \\ ${ }^{2}$ Faculty of Law, University of Wisnuwardhana Malang, Indonesia \\ ${ }^{3}$ Departement of Public Health, Faculty of Sport Science, Universitas Negeri Malang, Indonesia \\ ${ }^{4}$ Master of Law, Wisnuwardhana University Malang, Indonesia \\ $\triangle$ Corresponding Author: Dhian Kartikasari, E-mail: dhian.kartikasari.fik@um.ac.id
}

ARTICLE INFORMATION ABSTRACT

Received: February 16, 2021

Accepted: March 25, 2021

Volume: 3

Issue: 1

DOI: $10.32996 /$ ijlps.2021.3.1.4

\section{KEYWORDS}

People, ethics and political culture, democracy in Indonesian regions
The reformation initiated and marked by President Suharto's fall (21 May 1998) is essentially a demand to carry out democratization in all fields. In the Indonesian context, understanding ethics and political culture in the midst of demands for democratization in all fields is a necessity because the Indonesian nation is, in reality, a diverse nation, from the aspects of ethnicity, religion, race and inter-group (SARA), all of which obviously affect the pattern, style, ethical character, and political culture. This research aims to analyze the importance of the people's understanding of ethics and political culture in developing a democratic political culture in Indonesian regions. The method used is normative legal research by analyzing norms in the Indonesian constitution, laws, and other legal sources. The result of this research us that the efforts to understand the society's political ethics and culture based on Pancasila in the current reformation era, especially in regional areas, are significant because the Indonesian nation is carrying out reforms in all fields which, of course, require the support of all elements of society to behave in ethical ways and uphold a Pancasilabased culture. Various efforts to form ethical behaviors and culture based on Pancasila should be immediately carried out by both the state and all Indonesian citizens. These efforts, in addition to education, training, workshops and seminars, should be associated with Pancasila ideology, the noble values of Pancasila should be included in every statutory regulation in Indonesia, and which is no less important and in fact the most important, is the examples set by leaders, both at local and national levels, so that democratization which is the ideal of the reformation can be achieved in accordance with the noble values of Pancasila.

\section{Introduction}

The Indonesian state was proclaimed by Sukarno and Hatta on August 17, 1945, and is a large country supported by a number of advantages, ranging from geographical (Natural Resources), demographic (Human Resources), socio-cultural, to ideological advantages. Geographically, Indonesia is located at $6^{\circ} \mathrm{N}, 11^{\circ} \mathrm{S}$, and $95^{\circ} \mathrm{E}, 141^{\circ} \mathrm{W}$. It has some natural advantages with 15 million square kilometres, consisting of 3 million square kilometers of land and approximately 12 million square kilometres of oceans. Indonesia has 17,162 islands recorded at the Ministry of Home Affairs as of April 2020, but those verified at the UN in 2020 were only 16,671 because re-verification is needed (Dirjen Kemendagri.go.id); fertile land with two-season climate: the rainy season and the dry season; rich natural resources with diverse flora and fauna - Indonesia has 47,000 types of plants and 3025 species of animals. It has a strategic geopolitical position as a maritime country - located between the Asian Continent and the Australian Continent, and between the Pacific Ocean and the Indian Ocean - as a transpolitic-economic and cultural spot of the nations of the world, today and in the future. As a nation, Indonesia has 615 regional languages, 485 folk songs and 300 dance styles. As of

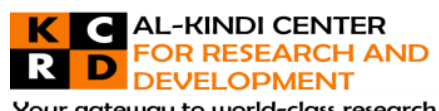

Your gateway to world-class research

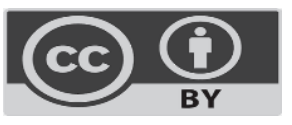

Published by Al-Kindi Center for Research and Development, United Kingdom. Copyright (c) the author(s). This open access article is distributed under a Creative Commons Attribution (CC-BY) 4.0 license 
the 2010 census, it has a very large population that amounting to 237.6 million people, divided into 10,068 ethnic groups. Indonesia population is in the top four in the world after China, India and the United States, and is a significantly important capital because the progress and decline of a nation are dependent on the Human Resources factor.

In addition, the socio-cultural plurality crystallized in the form of the values of the nation's philosophy of life (Pancasila philosophy) is the national identity, the national soul, the principle of state spirituality, and the source of national ideals as well as national identity and integrity, which are bound together in one tie of Bhinneka Tunggal Ika and the love of one's country and people. Furthermore, no less important is historical excellence. The Indonesian nation has golden eras, such as the glory of the Srivijaya state ( 8 c. -11 c.); and the glory of the Majapahit state (13 c. -14 c.), with geopolitical sovereignty beyond that of the current Republic of Indonesia, spreading from Taiwan to Madagascar. The Unitary State of the Republic of Indonesia has Pancasila as a national system, which radiates an identity as a religious-theistic philosophical system, as an excellent national value system in facing the challenges of the times. In the lives of the society, nation and state, the Indonesian nation is based on the ideological values of Pancasila, which also has superior values (Noor Syam, 2006:4).

These positive facts can be used as the primary capital for the Indonesian nation to rise and develop into a great, dignified, Pancasila nation, as well as to prosper both physically and mentally, from the backwardness of the Indonesian nation in various fields: economy, politics, culture, etc. In connection with this, various kinds of excellence, especially the abundant natural resource, must also be balanced with excellent and principled human resources, namely human resources that are independent, innovative, creative, honest, just, and have a high regard of familial, communal, national, and state life. Efforts to build the spirit and personality with values such as independent, innovative, creative, honest, just, and noble are through education (Wiyono, 2011:3).

The reformation initiated and marked by the fall of President Suharto (21 May 1998), is essentially a demand to carry out democratization in all fields by upholding law and justice, upholding human rights, eradicating corruption, collusion and nepotism, implementing Regional Autonomy and financial equality between the central and regional governments, and restructuring the roles and positions of the army and police. From the beginning of the reformation until now, the Indonesian nation is still in a transition period in every aspect of the society, nation and state. In the reformation era, changes took place very quickly and had a great impact, both positive and negative, on the lives of the society, nation and state. Such rapid changes and causing various kinds of crises have also resulted in the loss of the orientation of noble character, and ethical and cultural strength based on the Pancasila that had endured until then as the ancestral heritage of the Indonesian nation. This loss of the Indonesian people and nation's orientation has resulted in the flourishing of ethnocentrism, primordialism, physical conflicts, acts of terror, and the emergence of separatist movements.

The reformation movement would be more successful if the people understood an ethics and political culture based on Pancasila, to build a democratic political culture that had been the demand of the reformation. This is because the growth and development of democracy in a nation is closely related to the growth and development of the nation's ethics and socio-political culture. The more mature the ethics and socio-political culture of a nation is, the democracy created will be more ethical and has positive correlation with the achievement of the goals of a democratic governance, namely social welfare for its people as a whole. Conversely, the democratization process will not be able to run smoothly if it is not supported by the development of political attitudes and culture in accordance with the principles of democracy.

A political culture that is in accordance with the principles of democracy is manifested through its citizens' understanding of its political system through the orientation, views, and attitudes of the said political system. Therefore, a democratic political culture will support the creation of a democratic political system, and democratic political culture is a collection of belief systems, attitudes, norms, perceptions and the like that support the realization of public participation.

To find out the level of public understanding of ethics and political culture, in order to build a democratic political culture, the benchmarks used should not merely refer to the patterns of interaction constructed between individuals in dealing with and solving common problems. However, they should also refer to the whole of the interaction patterns, both interactions between individuals, between individuals with groups, and between individuals with their political systems and structures. In the Indonesian context, understanding ethics and political culture in the midst of demands for democratization in all fields is a necessity, because the Indonesian nation is in reality a diverse nation, from the aspects of ethnicity, religion, race and inter-group (SARA), all of which obviously affect the pattern, style, ethical character, and political culture. In social interactions in which there is a background of different aspects of SARA, there is a possibility of disagreements and misunderstandings as a result of the diversity of SARA backgrounds.

If not accompanied by efforts to understand each national entity's ethics and political culture, this situation will certainly hinder the process of democratization and will divide the spirit and soul of national unity and integrity formed so far. If this situation is

Page | 23 
not quickly ended, then the Indonesian nation will no longer be ethical, cultured, dignified and friendly, that upholds harmonious living in a society, courtesy, consensus democracy, mutual respect, tolerance for other groups, and mutual cooperation, which embody the values of humanism. Instead, there may be a culture that revels in violence and conflict, thuggery, criminalism, narrow fanaticism, primordialism and various other anarchist behaviors with racial nuances. This phenomenon, where there is a shift in social behavior from a humanist to one that likes violence and conflict, is supported by a number of facts where the escalation of social conflict is now relatively increasing, which will erode the bonds of solidarity between the citizens. This will threaten the unity and integrity of the nation, and destroy the noble values of Pancasila which are the foundation of ethics and political culture for the Indonesian people in achieving the objectives of the August 17, 1945 Proclamation as outlined in the Preamble to the 1945 Constitution.

\section{Pancasila As The Glue For The Life Of The Nation And State}

We must be grateful, if in recent times the longing for the noble values of Pancasila, which serve as the guideline for the nation and state, seems to have strengthened again. This has been shown, among other things, by the widespread discussion of Pancasila in various forums since 2005. Even at the 61st anniversary of Pancasila on June 1, 2006 at the Jakarta Convention Center (JCC), President Susilo Bambang Yudoyono delivered a political speech entitled Reorganizing the Framework for State Life based on Pancasila". The President invited the public to answer a fundamental question, "Why should we return to discussing Pancasila?". This affirmation invites the Indonesian nation to put Pancasila in the context of the true meaning of the reforms carried out today. Because in carrying out the life of the nation and state, especially in the current reformation era, it is obviously highly necessary to implement the noble values contained in Pancasila, so that the values, norms and attitudes described will truly be the integral parts that will fuse with the personality of individual in Indonesia, so that it may regulate and guide the behaviors and actions of the Indonesian people in carrying out the vision and mission of reformation.

At present, the things that are still good, appropriate and relevant, and which constitute the core identity and basic consensus, must be maintained. Meanwhile, anything that is not appropriate and is no longer suitable must be changed and renewed. To affirm the critical and fundamental questions above, President Susilo Bambang Yudhoyono emphasized, "let us make Indonesia a comfy turf where the diverse nation's children can meet, where we can build a consensus, to walk together in a life of harmony and tolerance".

In fact, if Pancasila is really understood, lived, and practiced in honesty and correct manner, consistently by every member of the society, especially state administrators and political elites in implementing the reformation to realize the aspired Indonesia, then Pancasila may become the glue that guides the power of national diversity to achieve the great and noble goal, in the form of upholding the sovereignty of the state for the benefit of the entire Indonesian citizens. Every movement, direction, and means carried out by members of society and state administrators and political elites must always be imbued with Pancasila. A whole and complete Pancasila will give Indonesia confidence that prosperity can be achieved as long as their life is based on appropriateness, accord, and equality. Therefore, the nation needs to be encouraged and guided by a noble world view as early as possible, because challenges in the future will be increasingly complex and weightier and require the Indonesian citizens to improve human resources without abandoning national ethics and culture that are based on the noble values of the Indonesian nation's ideology, namely Pancasila. According to Thompson (2000), as cited by Choirul Mahfud (2008:53), political ethics and public morality in the practices of democratization have become an urgent and interesting study because: (1) the political practice phenomenon has allegedly derailed off the way of political ethics and public morality; (2) the emergence of a new awareness in a democratic society about a good and clean governance based on morality and ethics.

Pancasila as the foundation of national ethics and culture is very much necessary. Pancasila values can answer problems in this era of disruption (Lonto and Pangalila, 2019). Philosophically, Pancasila can be developed into a universal cultural system, under the auspices of the first principle of the One God, as the main and highest value source of other principles, and under the final principle of Social Justice for All Indonesians as the goal of the independence struggles. Pancasila is undoubtedly a formidable weltanschaung (world view) for the Indonesian nation, so it demands that the principles be practiced in harmony, equality and as a whole, namely:

1. The principle of the One and Only God contains the basic concepts found in all religions and beliefs embraced by the Indonesian people. In connection with that, it is necessary to have a shared responsibility from all religious communities to lay a solid spiritual, ethical and cultural foundation for the national culture.

2. Just and Civilized Humanity's principle contains the basic concept of respect for human dignity. This principle places humans according to their nature and dignity and is not only in an equal manner, but also in a just and civilized manner. Therefore, it is the responsibility of all citizens of the nation and state of Indonesia to enhance the dignity and rights and obligations of mankind, eliminate colonialism, misery, and injustices from the earth's face. 
3. The Unity of Indonesia's principle contains the concept of the unity and integrity of the nation and territory of the Unitary State of the Republic of Indonesia with its diverse plurality. Therefore, cultivating and strengthening solidarity in the context of strengthening the unity and integrity of the nation and defending the Republic of Indonesia's territory is an obligation for all citizens within the nation and state of Indonesia.

4. The principle of the Democracy Guided by Wisdom in Deliberation / Representation, contains the basic concept of upholding the people's sovereignty, which in its implementation is carried out by hinging on the wisdom in deliberations / representatives. This requires all members of society, the nation, and the state to further develop a democratic political system based on Pancasila's values to maintain a dynamic national stability.

5. The principle of Social Justice for All Indonesian People contains the basic concept that welfare must be enjoyed by and touch all Indonesian people's levels. This means that there should also be an equitable development and high economic development and growth to create general welfare, or what is often referred to as a just and prosperous society based on Pancasila.

Pancasila contains national cultural values and becomes a source of national basic law and is a guiding star (leitstar) for the realization of noble ideals in all aspects of national life (Sudrajat, 2018; Herlambang, 2016). In other words, the values contained therein must also be translated into cultural norms, development norms, legal norms, and the ethics of national life. Thus, formally the Indonesian nation already has a strong foundation and clear guidelines for the development of the Indonesian society that it aspires to be. The problem is how to actualize the basis and boundaries into the real life of every individual citizen, so that this nation does not lose cultural norms as its guide and principle in implementing the reformation, and to overcome multi-dimensional crises, including cultural crises, that are hitting the nation and state in its efforts to achieve its aspired future.

Suppose the Indonesian nation cannot rise again to develop a political ethics and culture based on the noble values of Pancasila. In that case, it will be entombed with a transnational ideology (Capitalism) which was designed to be implemented as the only value that could unite humanity. Capitalism is operationally in the form of democratization, human rights, and free-market that rely on individualism, which today is widely praised as the world's best value and system.

\section{Public Understanding of Political Ethics and Culture Based On Pancasila}

The political policies of regional autonomy and decentralization introduced in the reformation era, among others, caused regional expansions in several provinces, districts and cities. As a result of the regional expansion, the number of provinces up to 2021 has amounted to 34 provinces, consisting of 416 regencies and 98 cities, and in accordance with the vision and mission of reformation each region is encouraged to be more democratic.

In order to encourage the strengthening of democracy and develop a democratic culture at the level of local government, the people must obviously understand and be willing to learn to develop democratic ethics and culture based on Pancasila. This is important because the success in building a democratic government is inseparable from the understanding and efforts of a society to learn by developing democratic ethics and culture. After all, democratic culture is basically a culture that originates and has roots in a society that develops and implements a ethical and democratically cultured governance pattern. On the other hand, this will be an impossibility when there is a formal political will to implement and develop democratic politics but not supported by actual democratic attitudes by the government or people.

A democratic government is basically one that prioritizes the freedom to build the participation of its citizens, which at the same time must be balanced with compliance with lawful legal norms, both on the side of the government and the citizens without any exceptions (equality before the law). Even Gabriel Almond (in Hanum, 2009: 7) stated that the success of a nation in building a democratic government, and the existence of a democratic socio-political culture and structure, is largely determined by the following variables:

1. A democratic culture is a mixed culture, namely between freedom/participation on one side and behavioral norms on the other;

2. A democratic culture is rooted in the culture of society in general, which contains high social trust and vividness with a tendency to horizontal/equal work relations;

3. A democratic culture always needs and is based on civil society;

4. A democratic culture is held by a society in a country and is especially dependent on the government's behaviour in practising democracy.

Thus, the reformation introduced in 1998 obviously did not immediately change Indonesia's political character from an authoritarian façade to a democratic and constitutional one. However, one way to realize a democratic and constitutional political system is to improve the quality of people's understanding of democratic ethics and culture, coupled with the willingness to learn through real life practices in family, society, nation and state.

Page | 25 
In relation to the current political transition process, the process to build democratic politics, as has been done by other nations in the world, according to Almond (Farida Hanum, 2009: 8), consists of three stages that must be passed, namely: a) the stage of developing democratic state institutions, b) the stage of creating and forming a pro-democracy character for the government and citizens, and c) the stage of creating a democratic social structure and political culture. The first stage in Indonesia can be seen after President Soeharto's fall in 1998. In the political and constitutional aspects, the People's Consultative Assembly (MPR) has made successive changes to the 1945 Constitution up to four times. Through this political commitment, new institutions were formed in addition to existing state ones to strengthen and accelerate the consolidation of democracy. In the second stage, the pro-democracy character at the time of the reformation had infused almost all Indonesian nation elements, both in the state apparatus and in the citizens. The third stage was taken by increasing the institutions' role, especially through civic education, national character education, community education on Bhinneka Tunggal Ika, national vision education, and other educations with content of strengthening and increasing people's understanding of democratic political ethics and culture based on Pancasila.

The real goal of the completion of these three stages of democratic development is to provide the people with the largest portion of role in the democratic development process. This is because the 23-years old political transition has caused a phenomenon in the form of boredom, skepticism and pessimism that has hit most people because they are increasingly losing confidence in the final results of reformation that remain vague. According to Massalissi (2011: 3), this situation was caused by 3 factors: first, there was an appropriation of the spirit of the reformation which the common people originally drove into an elitist movement. At first, reformation was voiced as the aspirations of the common people and university students. Then it became the aspirations of party elites and rulers so that it had an extraordinary interest bias. Claiming to act on behalf of the implementation of democracy, party elites used general elections to gain seats in the legislative body. Furthermore, through this legislative institution, they would have the right to say that they were the holder and channel of the people's aspirations. But in reality, they were only fighting for their own interests which were often different from and even contrary to the aspirations of the people they said they represented. Second, Reformation had no value bases, as can be seen in the current reformation era where the Indonesian people do not understand and cannot place knowledge that comes from local wisdom and cultural values rooted in the values of Pancasila in the spirit of reformation. Third, the involvement of various elements of society in overseeing the reforms has begun to ebb along with the lack of public access to political involvement in policy making. Society remains far from sources of power, both sources of power in the form of authority, information, law, funds and others.

This situation, of course, will eventually lead to a shift in the pattern of democratic development, namely that democracy which students originally drove and the common people later became dominated by elites, ranging from the economic elites to the political party elites. Thus, the developing democracy, both in terms of the content of its objectives and the accommodated interests, became an elite democracy that prioritized the nation's elite's interests. In the end, various national problems that were urgently in need for solutions became neglected.

The various existing national problems remain an arena for criticism as a form of control over the government's performance in safeguarding and realizing the ideals of reformation and democracy. However, several national problems have so far not only become the domain of criticism by the society but have also triggered various mass conflicts in the regional areas, and actually the socio-political conflicts in Indonesia have increasingly got more intense since the reformation era.

Based on the data on the potential conflict map of LIPI (Indonesian Institute of Science) in 2018, the implementation of the culture of political democracy in regional areas has the potential for conflict. Several conflicts that have the potential to occur during the implementation of democracy are conflicts within religious communities which range from very bad $(0.7 \%)$, bad (27.0\%), good $(0.7 \%)$, to very good (11\%); inter-religious relations which range from very bad (2.8\%), bad (22.8\%), good $(5.5 \%)$, to very good (9\%); inter-ethnic relations which range from very bad $(2.1 \%)$, bad $(22,1 \%)$, to good $(0.7 \%)$; socioeconomic class relations which range from very bad (4.1\%), bad (44.8\%), good (40.9\%), to very good $(3.4 \%)$ ). One conflict that needs serious attention is the relations between socioeconomic classes. Although $50.3 \%$ of expert respondents answered that the conditions were good and very good, $48.9 \%$ of other expert respondents said the conditions were bad and terrible. Based on the LIPI survey (2018) regarding the potentials for conflict, the potential for political conflicts ranges from very low (12\%), low $(67 \%)$, to high (21\%); the potential for economic conflicts range from very low (16\%), low (59\%), to high (25\%); the potential for socio-cultural conflicts range from very low $(17 \%)$, low $(51 \%)$, high $(29 \%)$, to very high $(2 \%)$; the potential for defense and security conflicts range from very low (17\%), low (53\%), to high (30\%).

As shown by these facts that there are so many national problems that have not been thoroughly addressed, the implementation of democracy in Indonesia is not yet in accordance with the noble values of Pancasila. This will likely have an impact in the form of the low effectiveness of government performance. 


\section{Conclusion}

Efforts to understand the society's political ethics and culture based on Pancasila in the current reformation era, especially in regional areas, are very important because the Indonesian nation is carrying out reforms in all fields which, of course require the support of all elements of society to behave in ethical ways and uphold a Pancasila-based culture. The various kinds of alarming behaviors found today, whether social, political, or religious, that have influenced the growth and development of democratization in regional areas are, in essence, an indication that there are still many kinds of national problems that are resolved using physical conflicts and violence.

Therefore, various kinds of efforts to form ethical behaviors and culture based on Pancasila should be immediately carried out by both the state and all Indonesian citizens. These efforts, in addition to education, training, workshops and seminars, should be associated with Pancasila ideology, the noble values of Pancasila should be included in every statutory regulation in Indonesia, and which is no less important and, in fact, the most important, is the examples set by leaders, both at local and national levels, so that democratization which is the ideal of the reformation can be achieved in accordance with the noble values of Pancasila.

Indeed, to achieve national goals as outlined in the Preamble to the 1945 Constitution of the Republic of Indonesia necessitates the entire Indonesian nation to struggle in various aspects of real life. Sukarno conveyed this in his speech at the Indonesian Independence Preparatory Investigation Agency (BPUPKI) on June 1, 1945, which among other things stated, "... ..that no weltanschaung can manifest itself, become a reality itself. No weltanschaung can become a reality, become realiteit, if not through struggle".

In addition, Sukarno also stated: "... ..that Pancasila is a philosofisce grondslag, a foundation, philosophy profound thought, which is the foundation or basis for the independent state to be established". Furthermore, it was also stated that besides serving as a foundation for the establishment of the nation state, Pancasila also functions as a guiding star or leitstar, as a national ideology, as a view of the nation's life, as a glue or unifier of the nation and as a basic insight of the Indonesian nation in achieving its national goals.

In this regard, if the Indonesian nation does not want to lose its identity, and does not want to be entombed with the ideology of capitalism, then there is no other choice except to fight for Pancasila ethics and culture in all aspects of society, nation and state, continuously and unwavering, so that soon a just and prosperous society can be realized based on Pancasila, which the founders of the Unitary State of the Republic of Indonesia had aspired to and which obviously was also aspired to by the whole Indonesian nation.

\section{References}

[1] Budimansyah, D .(2002). Penguatan Pendidikan Kewarganegaraan Untuk Membangun Karakter Bangsa (Strengthening Civic Education to Build National Character), Widya Aksara Press, Bandung

[2] Hanum, F (2009). Etika dan Budaya Politik di Era Perkembangan Otonomi Daerah (Political Ethics and Culture in the Era of the Development of Regional Authority), quoted from http.www.google.com, accessed 16 April 2009.

[3] Haluan, K (2011). Demokrasi dan Konflik Di Daerah (Democracy and Conflicts in Regions), quoted from http.www.haluan krpi.com, accessed 8 April 2012.

[4] Herlambang. (2015). Understanding Pancasila Position as the Fundamental Norm "Grundnorm" of Indonesia Law. South East Asia Journal of Contemporaru Busines, Economic, and Law, 145-155

[5] Lembaga Pengkajian dan Pengembangan Kehidupan Bernegara (LPPKB), 2011, Pancasila, Jakarta

[6] Lonto, A. P. (2019). The Existence of Pancasila Values in the Disrupted Era. The First International Conference on Education, Social Science and Humanities (pp. 145-149). Advances in Social Science, Eduaction and Humanities Research

[7] Mahfud, C (2008). Etika Politik, Budayaitas Publik dan Demokratisasi di Aras Lokal (Political Ethics, Culturality of the Public and Democratization in Local Areas), Jurnal Cakrawala, vo.2 No. 2 June

[8] Massalissi (2011). Demokrasi dan Problemnya di Daerah (Democracy and Its Regional Problems), quoted from http.www.google.com, accessed 7 March 2011.

[9] Noor, S, Moh (2006). Negara Kesatuan Republik Indonesia Sebagai Sistem Kenegaraan Pancasila (Wawasan Filosofis, Ideologis dan Konstitusional untuk Membudayakan Wawasan Nasional) (The Unitary State of the Republic of Indonesia as a State System Based on Pancasila [Philosophical, Ideological and Constitutional Insights to Cultivate a National Insight]), Unair, Surabaya

[10] Noor, S. Moh (2008). Pembudayaan Filsafat Pancasila Sebagai Ideologi Negara Menegakkan Wawasan Nasional Dalam Integritas NKRI Sebagai Nation State (Cultivating the Philosophy of Pancasila as National Ideology to Implement National Insight in the Context of the Integrity of NKRI as a Nation State), paper presented at the National Seminar on 21 December 2008, held by UM Pancasila Laboratory in cooperation with the Directorate of National and Political Unitary Agency, Ministry of Interior Affairs.

[11] Suhatmansyah (2012). Institusionalisasi Nilai-Nilai Pancasila Dalam Pembangunan Karakter Bangsa (Instututionalization of Pancasila Values in the Development of National Character), paper presented at Pancasila Congress on 30 - 31 May 2012 MPR RI, Jakarta

[12] Tedi, S (2018). Harmonization of Regulation Based on Pancasila Values Through The Constitutional Court of Indonesia. Constitutional Review, 301-325. 
[13] Vivinzeey (2012). Pengaruh Budaya Politik Terhadap Perkembangan Demokrasi Di Indonesia (The Influences of Political Culture on the Development of Democracy in Indonesia). retrieved from http.www.google.com, accessed on 22 March 2012

[15] Wiyono, S (2011). Kearifan Lokal Sebagai Penyangga Persatuan Dan Kesatuan Bangsa, (Local Wisdom as the Pillar of National Unity and Harmony), paper presented in "Convention for Strengthening Access to Local Wisdom in Social Disaster Management", held by the Social Agency of East Java Province, 2011, Thursday, 28 July 2011, "Surya Indah" Hotel, Batu City, East Java.

[16] Wiyono, S (2011). Peran Pancasila Sebagai Perekat Kebhinnekaan, Makalah disampaikan dalam Seminar Menciptakan Persatuan dan Kesatuan Bangsa dengan Tetap Menghormati Realita Kebhinnekaan (The Role of Pancasila as the Glue of Diversity), paper presented in the Seminar on Creating National Unity and Harmony while Respecting the Reality of Diversity, held by Bakesbangpol of Malang Regency, 21 December 2011 